\title{
Informacje/Information
}

DOI : $10.14746 / \mathrm{pp} .2014 .20 .2 .14$

\section{Sprawozdanie z konferencji naukowej pt. „Partycypacja obywateli w procesie podejmowania decyzji politycznych. Aktywność vs. bierność polityczna w Polsce i w Europie" (Collegium Polonicum w Słubicach, 28-29 maja 2015 roku)}

W dniach 28-29 maja 2015 r. w Collegium Polonicum w Stubicach - wspólnej placówce naukowo-badawczej Uniwersytetu im. Adama Mickiewicza w Poznaniu oraz Uniwersytetu Europejskiego Viadrina we Frankfurcie nad Odrą - odbyła się druga konferencja poświęcona zagadnieniu partycypacji obywateli w procesie podejmowania decyzji politycznych. Tegoroczne obrady skupiły się wokół kwestii aktywności i bierności politycznej w Polsce i w Europie. Organizatorami wydarzenia byli Zakład Systemów Politycznych Wydziału Nauk Politycznych i Dziennikarstwa UAM, Grupa Badawcza „Inicjatywa Helwecka”, Polskie Towarzystwo Nauk Politycznych Oddział w Poznaniu oraz Fundacja na rzecz Collegium Polonicum.

Konferencja stworzyła sposobność do wymiany opinii i poglądów oraz prezentacji wyników badań na temat dotychczasowych uwarunkowań, doświadczeń i wyzwań związanych z udziałem obywateli w procesach podejmowania decyzji politycznych w oparciu o doświadczenia polskie i państw europejskich. Poziom partycypacji obywatelskiej, a także różne formy uczestnictwa obywatelskiego, stanowią ważny element dyskusji na temat kondycji współczesnej demokracji.

W trakcie obrad konferencji uwaga została skupiona wokół zagadnienia partycypacji i bierności obywateli w perspektywie teoretycznej i praktycznej. W tym kontekście ukazano relacje między deficytem demokratycznym a partycypacją obywatelską; dokonano omówienia form partycypacji obywateli w procesie decydowania politycznego na poziomie regionalnym, państwowym i ponadnarodowym; przedstawiono determinanty niskiej frekwencji wyborczej; poddano analizie wpływ działalności organizacji społecznych na rzecz zaangażowania obywateli w procesie podejmowania decyzji politycznych, a także omówiono alternatywne formy partycypacji obywateli oraz dokonano próby oceny ich efektywności.

Podczas konferencji „Partycypacja obywateli w procesie podejmowania decyzji politycznych. Aktywność vs. bierność polityczna w Polsce i w Europie" odbyły się obrady plenarne oraz dziewięć paneli tematycznych. Udział wzięło w sumie 59 prelegentów. Konferencję otworzył Dziekan Wydziału Nauk Politycznych i Dziennikarstwa UAM prof. dr hab. Tadeusz Wallas, który w swym wystąpieniu zwrócił szczególną uwagę na aktualność i ważkość tematów podejmowanych w trakcie konferencji. Drugiego dnia konferencji odbył się wyjazd studyjny do Berlina, podczas którego uczestnicy odbyli wizytę w Bundesracie.

W trakcie obrad plenarnych wygłoszono siedem referatów. Konferencję otwarło wystapienie dr hab. Lecha Szczegóły z Uniwersytetu Zielonogórskiego o źródłach bierności Polaków. Z problemem tym korelowało wystąpienie prof. Marka Żyromskiego (WNPiD UAM), który podjął się tematu absencji wyborczej w Polsce jako przykładu nie-działania. Prof. Krzysztof Łabędź z Akademii Ignatianum zaprezentował referat na temat form i ograniczeń partycypacji obywatelskiej na poziomie lokalnym, natomiast prof. Jerzy Leszkowicz-Baczyński (Uniwersytet Zielonogórski) skupił się na budżecie partycypacyjnym jako sposobie aktywizacji społeczności miejskich. W drugiej części obrad plenarnych dr hab. Renata Duda (Uniwersytet Wrocławski) wygłosiła prelekcję pt. Program partycypacji obywatelskiej w Stanach Zjednoczonych. Analiza porównawcza zaangażowania obywateli USA $i$ Unii Europejskiej w realizację programów o charakterze lokalnym, zaś 
prof. Bogdan Koszel z WNPiD UAM dokonał analizy procesu budowy społeczeństwa obywatelskiego (Zviligesellschaft) w zjednoczonych Niemczech. Obrady plenarne zamknęło wystapienie Adama Szulczewskiego z Fundacji na rzecz Collegium Polonicum dotyczące roli organizacji pozarządowych w partycypacji obywatelskiej. A. Szulczewski ują ten problem z perspektywy partycypanta. Sesję plenarną zamknęła dyskusja.

Po przerwie obiadowej rozpoczęły się obrady w dziewięciu panelach. Panele te zostały podzielone na 5 bloków tematycznych i dotyczyły następujących zagadnień: udziału obywateli w procedurach wyborczych; form aktywności obywateli na poziomie lokalnym; partycypacji społecznej w Europie i na świecie; partycypacji społecznej w Polsce; oraz zaangażowania społecznego na poziomie lokalnym w wymiarze praktycznym.

W ramach bloku tematycznego dotyczącego udziału obywateli w procedurach wyborczych zostało wygłoszonych 13 referatów. Obrady odbywały się w dwóch następujących po sobie panelach. W pierwszej turze, moderowanej przez prof. Bogdana Koszela (WNPiD UAM), podjęto tematy: alternatywnych procedur głosowania i ich wpływu na zwiększenie frekwencji wyborczej; determinantów zachowań wyborczych Polaków; wpływu religii na zachowania wyborcze; powszechnego głosowania korespondencyjnego i innych ułatwień podczas wyborów prezydenckich w Polsce w 2015 r.; form inicjatyw i działań zmierzających do wzrostu partycypacji w wyborach w Polsce; a także wpływu Internetu na głosowanie, wybory i wyborców. W drugiej turze wystąpień z tego panelu tematycznego prelegenci wygłosili referaty na temat: personalizacji wyborów i jej wpływie na wyborczą partycypację obywateli (casus wyborów prezydenckich w Poznaniu w 2014 roku); problemu absencji wyborczej w wyborach samorządowych; frekwencji wyborczej na poziomie gminnym (casus gminy Dobra Szczecińska); uwarunkowań transportowych niskiej frekwencji wyborczej; jednomandatowych okręgów wyborczych; elektronicznych platform komunikacyjno-konsultacyjnych; oraz efektywności alternatywnych form głosowania. Panel ten moderował dr hab. Lech Szczegóła z Uniwersytetu Zielonogórskiego. Po obu panelach odbyła się dyskusja.

$\mathrm{Na}$ drugi blok tematyczny, dotyczący form aktywności obywateli na poziomie lokalnym, składało się dziewięć referatów rozłożonych w dwa panele. W pierwszej części obrad skupiono uwagę na problemach: obywatelskiej inicjatywy uchwałodawczej w polskim systemie prawnym; form partycypacji obywateli w samorządzie lokalnym w podejmowaniu decyzji politycznych w Polsce; oddolnego przedstawicielstwa politycznego w Warszawie w kontekście startu ruchów miejskich w wyborach samorządowych w 2014 roku; a także partycypacji na poziomie sublokalnym, czyli o poznańskich wyborach do rad osiedli w 2015 roku. Panelowi temu przewodniczył prof. Krzysztof Łabędź (Akademia Ignatianum). Druga tura tego bloku tematyeznego skupiała się wokół zagadnień: społecznej aktywizacji na poziomie lokalnym (casus działalności Fundacji na rzecz Collegium Polonicum); strategii wyborczej mniejszości niemieckiej w wyborach samorządowych i parlamentarnych; partycypacji obywatelskiej w obszarze zarządzania kryzysowego na poziomie gminnym; nowoczesnego narzędzia partycypacji społecznej, jakim jest 'Bottom up'; oraz politycznego wymiaru pamięci zbiorowej o okresie PRL. Panel ten moderował prof. Jerzy Leszkowicz-Baczyński z Uniwersytetu Zielonogórskiego.

W bloku tematycznym pt. Partycypacja spoleczna w Europie i na świecie wygłoszono 11 referatów. Pierwszemu panelowi w tym bloku przewodniczyła dr hab. Renata Duda (Uniwersytet Wrocławski), drugiemu zaś prof. Jędrzej Skrzypczak (WNPiD UAM). W referatach poruszono kwestie: przemian form aktywności politycznej obywateli; partycypacji obywateli wybranych państw europejskich w procesie podejmowania decyzji w zakresie polityki energetycznej; instytucji 'Recall election ' w brytyjskim prawie parlamentarnym; słabnącego zainteresowania Szwajcarów partycypacją społeczną; miejsca głowy państwa i obywateli w systemie politycznym Liechtensteinu w kontekście jego dwufilarowości; frekwencji wyborczej w nowych landach RFN 25 lat po zjednoczeniu; obowiązkowemu głosowaniu w Belgii jako skutecznej metodzie zwiększania partycypacji obywateli w wyborach; nordyckiemu modelowi partycypacji i społeczeństwu norwes- 
kiemu wobec członkostwa w UE; wpływu opinii publicznej w Niemczech na politykę rządu A. Merkel wobec konfliktu na Ukrainie; partycypacji-performatyzacji-polityki (casus Pussy Riot); a także aktywności rosyjskich obywateli w ramach organizacji społecznych. Po wystapieniach prelegentów odbyła się dyskusja.

Na blok tematyczny dotyczący partycypacji społecznej w Polsce złożyło się w sumie 11 referatów, wygłoszonych, podobnie jak w poprzednich przypadkach, w dwóch panelach. Pierwszemu przewodniczyła dr hab. Małgorzata Podolak (UMCS). Wygłoszono w nim referaty na temat: Res publica feudalis; partycypacji kobiet w przestrzeni medialnej w Polsce; partycypacja wyborcza młodzieży studiującej (casus studentów Uniwersytetu Zielonogórskiego); integracji europejskiej jako czynnika wzmacniającego autonomię premiera (casus Polski). Prof. Marek Żyromski (WNPiD UAM) moderował panelem, w którym podjęto zagadnienia: prawyborów w polskiej praktyce politycznej; nieskutecznych inicjatyw referendalnych w Polsce w latach 2007-2014; wyborów w Polsce Ludowej lat 1947-1989; wpływów rządów prawicowo-populistycznych w latach 2005-2007 w Polsce na stosunek do demokracji oraz partycypację polityczną obywateli; debat oksfordzkich jako przykładu partycypacji społecznej; oraz zarządzania partycypacyjnego w przedsiębiorstwie odpowiedzialnym społecznie.

W ostatnim panelu przeprowadzono dyskusję na temat praktycznego wymiaru zaangażowania społecznego na poziomie lokalnym. Dyskusję moderowali prof. Magdalena Musiał-Karg i Adam Szulczewski z FCP. Wprowadzenie do niej stanowiły dwa wystapienia: dr. Pawła Antkowiaka (WNPiD UAM) pt. Konsultacje spoleczne na poziomie lokalnym-25 lat doświadczeń samorzqdowych oraz dr. Marcina Rachwała (WNPiD UAM) - Uwarunkowania partycypacji mieszkańców w referendach lokalnych w Polsce. Zaproszonymi uczestnikami dyskusji byli: Marek Cebula (Burmistrz Krosna Odrzańskiego), Magdalena Tokarska (Prezes Fundacji na rzecz Collegium Polonicum), Tomasz Kaczmarek (Dyrektor ZEAS w Krośnie Odrzańskim), Kamil Szlosek (Sektor 3 Słubice), dr Elżbieta Lesiewicz (WNPiD UAM), dr Michał Tomczyk (Uniwersytet w Lucernie, Szwajcaria, WNPID UAM), dr Ryszard Bodziacki (WNPiD UAM) oraz Robert Włodek (Slubiczanie.pl, „Pogranicze Lubuskie”).

Dzięki wielu spostrzeżeniom, dogłębnej analizie zjawiska i wielowątkowej dyskusji, zrealizowano zamierzone cele konferencji, umożliwiając jednocześnie integrację środowiska badaczy oraz wymianę opinii i doświadczeń. 